\title{
Multiprofessional instrument for tracheal decannulation in adults: content validity
}

\author{
Instrumento multiprofissional para decanulação traqueal em adultos: validação de conteúdo \\ Instrumento multiprofesional para decanulación traqueal en adultos: validación de contenido
}

Received: 01/12/2022 | Reviewed: 01/16/2022 | Accept: 01/20/2022 | Published: 01/22/2022

\author{
Paulo Henrique Coltro \\ ORCID: https://orcid.org/0000-0002-0548-3561 \\ Universidade Tuiuti do Paraná, Brazil \\ E-mail: paulo_coltro@hotmail.com \\ Isabel de Lima Zanata \\ ORCID: https://orcid.org/0000-0002-0902-5584 \\ Universidade Tuiuti do Paraná, Brazil \\ E-mail: isabelzanata@hotmail.com \\ Tatiane Caroline Boumer \\ ORCID: https://orcid.org/0000-0001-8538-5410 \\ Pontifícia Universidade Católica do Paraná, Brazil \\ E-mail: tatianeboumer@gmail.com \\ Ana Paula de Andrade Sartori \\ ORCID: https://orcid.org/0000-0002-9633-7905 \\ Universidade Tuiuti do Paraná, Brazil \\ E-mail: anapaulafono10@gmail.com \\ Rosane Sampaio Santos \\ ORCID: https://orcid.org/0000-0001-6400-5706 \\ Universidade Tuiuti do Paraná, Brazil \\ E-mail: rosane.santos2@utp.br
}

\begin{abstract}
Introduction: Tracheal decannulation needs multiprofessional evaluation observing success predictor criteria. A validated instrument can increase the safety of the procedure, reduce the length of stay and ensure better quality of life. Objective: To develop and perform the content validity of a multiprofessional instrument for tracheal decannulation in adults. Method: Cross-sectional descriptive study, with 24 judges: doctors, physiotherapists, speech therapists and nurses. The instrument was developed and presented through an electronic form where the judges took their notes. The Content Validity Index by item (CVI-I) and total (CVI-T) were calculated to verify evidence of validation. In unverified items, adjustments were made pointed out by the judges and submitted to the new evaluation phase in order to obtain complete validation of the instrument. Results: First evaluation phase, the items: Identification, Ventilatory History, Vital Signs, Consciousness/Collaboration, Ventilatory Data, Opinion and Legend obtained CVI-I > 0.78, were considered validity. The items Muscular Performance and Speech and Swallowing did not obtain adequate validity CVI-I 0.67 and 0.17 , respectively. Therefore, they were submitted to the second phase of evaluation. In this phase, these items were validated obtaining CVI-I $=0.83$ in the item Muscular Performance and CVI-I=1.0 in the item Speech and Swallowing. From the mean of CVI-I, the value CVI-T $=0.9$ was obtained, validity all the instrument. Conclusion: Multiprofessional instrument that can help in the process of tracheal decannulation in adults was developed and validity in content post two phases of evaluation by a group of expert judges in the area.
\end{abstract}

Keywords: Tracheostomy; Weaning; Airway management; Validation study.

\section{Resumo}

Introdução: A decanulação traqueal necessita da avaliação multiprofissional observando critérios preditores de sucesso. Um instrumento validado pode aumentar a segurança do procedimento, reduzir o tempo de internamento e garantir maior qualidade de vida ao paciente. Objetivo: Elaborar e realizar a validação de conteúdo de um instrumento multiprofissional para decanulação traqueal em adultos. Metodologia: Estudo descritivo transversal, com 24 juízes: médicos, fisioterapeutas, fonoaudiólogos e enfermeiros. O instrumento foi desenvolvido e apresentado por meio de formulário eletrônico onde os juízes realizaram seus apontamentos. Foram calculados os Î́ndices de Validade de Conteúdo por Item (IVC-I) e Total (IVC-T), para verificar evidência de validação. Em itens não validados, foram realizados ajustes apontados pelos juízes e submetido à nova fase de avaliação a fím de obter a validação completa do instrumento. Resultados: Na primeira fase de avaliação os itens: Identificação, Histórico Ventilatório, Sinais Vitais, Consciência/Colaboração, Dados Ventilatórios, Parecer e Legenda obtiveram IVC-I > 0,78, portanto foram considerados validados. Os itens Performance Muscular e Fonação e Deglutição não obtiveram IVC-I adequado, IVC-I $=0,67$ e 0,17 , respectivamente. Portanto foram submetidos à segunda fase de avaliação. Nessa, esses itens foram validados obtendo IVC-I=0,83 no item Performance Muscular e IVC-I=1,0 no item Fonação e Deglutição. A partir da 
média de IVC-I, foi obtido o valor IVC-T 0,9 validando este instrumento em sua totalidade. Conclusão: Foi elaborado, com base na literatura científica, um instrumento multiprofissional que pode auxiliar no processo de decanulação traqueal em adultos e que foi validado em conteúdo após duas fases de avaliação por um grupo de juízes especialistas na área.

Palavras-chave: Traqueostomia; Desmame; Manuseio das vias aéreas; Estudos de validação.

\section{Resumen}

Introducción: La decanulación traqueal requiere evaluación multiprofesional, observando criterios predictivos de éxito. Un instrumento validado puede aumentar la seguridad del procedimiento, reducir la estancia hospitalaria y garantizar una mejor calidad de vida al paciente. Objetivo: Desarrollar y realizar la validación de contenido de un instrumento multidisciplinario para la decanulación traqueal en adultos. Metodología: Estudio descriptivo transversal, con 24 jueces: médicos, fisioterapeutas, logopedas y enfermeras. El instrumento fue desarrollado y presentado a través de un formulario electrónico donde los jueces tomaron sus notas. Se calcularon los Índices de Validez de Contenido por Ítem (VCI-I) y Total (VCI-T) para verificar la evidencia de validación. En los ítems no validados, se realizaron los ajustes indicados por los jueces y se sometieron a una nueva fase de evaluación para obtener la validación completa del instrumento. Resultados: En la primera fase de evaluación, los ítems: Identificación, Historia Ventilatoria, Signos Vitales, Conciencia/Colaboración, Datos Ventilatorios, Opinión y Leyenda obtuvieron VCI-I > 0,78, por lo tanto, se consideraron validados. Los ítems Rendimiento Muscular y Fonación y Deglución no obtuvieron un VCI-I adecuado, VCI-I=0,67 y 0,17, respectivamente. Por lo tanto, fueron sometidos a la segunda fase de evaluación. En eso, estos ítems fueron validados obteniendo VCI-I=0,83 en el ítem Rendimiento Muscular y VCI-I=1,0 en el ítem Fonación y Deglución. A partir de la media del VCI-I se obtuvo el valor de VCI-T 0,9, validando este instrumento en su totalidad. Conclusión: Con base en la literatura científica, se desarrolló un instrumento multiprofesional que puede auxiliar en el proceso de decanulación traqueal en adultos, el cual fue validado en contenido luego de dos fases de evaluación por un grupo de jueces expertos en el área.

Palabras clave: Traqueostomía; Destete; Manejo de la vía aérea; Estudio de validación.

\section{Introduction}

Tracheostomy has benefits in patients who need prolonged periods of mechanical ventilation (Hosokawa et al., 2015), however, it can also trigger several mechanical and physiological changes (Santus et al., 2014), that can compromise the individual's quality of life. Which leads the Tracheostomy decannulation (removal of tracheostomy tube), an important step in the recovery from chronic critical illness (O’Connor \& White, 2010).

The process of decannulation includes a multidisciplinary approach and should be performed by the cooperation between physicians, physiotherapists and speech therapists. Include all professional who caring for patients with tracheostomy (nurses, occupational therapists, psychologists, professional of rehabilitation) (Medeiros et al., 2019) .

In the literature review there is a lack of standardization as a results the absence of national guidelines to guide the Sistema Único de Saúde (SUS) and the Agência Nacional de Saúde (ANS), which is reflected in the lack of availability of material needed to care for these patients, such as tracheostomy cannulas in the medical care services, as well as the lack of training of the medical and non-medical teams that treat these patients (Avelino et al., 2017).

There is a lack of evidence to inform when a tracheostomy tube should be removed. Some patients need to remain with the tracheostomy for a long time. Long-term care of the patient with a tracheostomy can be fragmented, such that the clinicians faced with the decision to decannulate are often not the same physicians who inserted the tracheostomy (Hess \& Altobelli, 2014).

The safe decannulation of patients undergoing tracheostomy must have: the first step for a successful decannulation is the recovery from chronic and critical illness, its means that this can be done only when the indication for the tube placement has resolved. The second step should be the assessment of the functional situation of breathing, speech and swallowing, because the tracheostomy leads to changes in ventilation, voice and food. And can also leave an anatomical airway obstruction with airflow obstruction (Bernardi, 2016).

A systematic approach to patient evaluation, along with judicious use of airway endoscopy, can help identify barriers to decannulation. Some studies (Hess \& Altobelli, 2014; Hess \& Faarc, 2005) suggest the use of speech valves, plugs and also the 
gradual reduction of the tracheostomy cannula to continue the tracheal decannulation process and if the individual is unable to tolerate these measures, submit it the computed tomography and endoscopy to look at the upper airway pathology.

Although these resources contribute to the process of removing the tracheal cannula, they may not be consistent with the reality of health systems, as they are costly. Therefore, it is important that clinical measures are able to assist in the decision to decannulate the patient and when the clinical diagnosis is not conclusive, relying on more expendable resources.

With this, studies sought to create instruments that would help in this process in an objective way. A preliminary study proposed an instrument for tracheal decannulation where the criteria used were pressure and pulmonary flow measurements as indicative for decannulation and concluded that these had no direct relationship with tracheal decannulation (Mendes et al., 2008). In a review article related to weaning and removal of the tracheostomy, a protocol for tracheal decannulation was developed, where the authors propose directions for decannulation, but do not use clinical criteria and specific measures for decision making, it is only a process directions of how to proceed with the decannulation (Mendes et al., 2013).

In another review, the authors bring articles that propose tracheal decannulation, and based on these propose some criteria for decannulation such as level of consciousness and respiratory distress (Hausberger et al., 2016), but as in the other protocols mentioned above, no specific clinical criteria and outcome measures were found that can safely guide the professional in making the decision to decannulate the patient.

In these three proposals, the author approach the creation for tracheal decannulation protocols, allows a thorough and safe approach, in an integrated manner, improving the provision of assistance with higher quality and emphasize the importance of continuing research on the subject, as soon as its results are still incipient. Therefore, it is still necessary to determine more specific criteria regarding respiratory mechanics, level of consciousness and speech and swallowing by compiling them into an instrument capable of guiding the professional in evaluating the patient.

Join criteria of an instrument for decannulation and the search for its evidence of validity can facilitate the evaluation process, since it standardizes and systematizes this action, bringing greater assertiveness and reducing the risk of failure in the process (Hausberger et al., 2016). The validation of an instrument reflects the concern in analyze and provide available evaluation tools that have reliability and reduce subjective judgments, thus bringing excellence and quality to the evaluation (Medeiros et al., 2015).

The proposal to elaborate and validity in content a multiprofessional instrument arises from the need to list the criteria of greater frequency in literature. The validity this instrument through the trial of a group of expert judges in the area confirms the relevance of defining these criteria (Pernambuco et al., 2017).

Therefore, the objective this study is to develop and validity in content a multiprofessional instrument for tracheal decannulation in adults.

\section{Methodology}

Descriptive, cross-sectional, quantitative and content validity study (Souza et al., 2017; Pereira et al., 2018). The research was submitted to the Research Ethics Committee of the Tuiuti University of Paraná for evaluation of ethical feasibility under approval number 2.967.499.

\section{Stage I - preparation of the instrument}

The elaboration of the instrument started after the literature review using MEDLINE, EMBASE, LILACS, SciELO, PubMed, ClinicalKey and Cochrane databases. The search was performed in articles in Portuguese, English and Spanish. The following health descriptors DeCs and MeSH Terms were used: tracheostomy, weaning, decanulation, validation studies and 
tracheostomy protocols, weaning, deccannulation, validation studies, protocols, tracheostomy, destete, decanulación, validación studies.

Post bibliographic survey, the articles found were read and analyzed in order to verify the recurrence and similarities of criteria for tracheal decannulation. The selected articles were used as a subsidy for the elaboration of the instrument, which in its initial version contemplated nine items distributed in a logical and coherent manner with the clinical practice: (1) patient identification, (2) ventilatory history, (3) vital signs, (4) consciousness/collaboration, (5) ventilatory data, (6) muscle performance, (7) speech and swallowing, (8) opinion and (9) legend (Supplement 1).

\section{Stage II - content validity}

To validity content, judges were selected in the professional categories that work in the theme of the study. The quantitative for the composition of this sample was based on the findings of the literature, which although it is not consensual reports that the recommended number of judges is between six and 20 individuals, because in studies with lower samples there would be no statistical relevance and with a higher number there would be saturation in opinions (Medeiros et al., 2015).

A sample was defined for convenience of six judges from each of the study's areas of scope and provided assent to participate in the research: physiotherapists, speech therapists, doctors and nurses.

Two items of the instrument were specific to two professional areas, "speech and swallowing" were evaluated only by the professional group of speech therapists and the item "muscle performance" was evaluated only by the professional group of physiotherapists. The other characteristics of the sample of judges are presented in Table 1, distributed on the basis of maximum degree of titulation, time of performance and experience in the area, separated by profession.

Table 1 - Characteristics of judges, separated by profession.

\begin{tabular}{|c|c|c|c|c|c|c|}
\hline \multirow{2}{*}{\multicolumn{2}{|c|}{ Professional profile }} & \multicolumn{4}{|c|}{ Profession } & \multirow[b]{2}{*}{$\begin{array}{l}\text { Total } \\
(\mathrm{n}=\mathbf{2 4})\end{array}$} \\
\hline & & $\begin{array}{r}\text { Nurse } \\
(n=6)\end{array}$ & $\begin{array}{l}\text { Physiotherapist } \\
\qquad(\mathrm{n}=6)\end{array}$ & $\begin{array}{l}\text { Speech Therapist } \\
\qquad(n=6)\end{array}$ & $\begin{array}{c}\text { Doctor } \\
(n=6)\end{array}$ & \\
\hline \multicolumn{7}{|l|}{ Degree n $(\%)$} \\
\hline & Expert & $3(50.0 \%)$ & $2(33.3 \%)$ & $0(0 \%)$ & $4(66.7 \%)$ & $9(37.5 \%)$ \\
\hline & Master & $1(16.7 \%)$ & $2(33.3 \%)$ & $3(50.0 \%)$ & $2(33.3 \%)$ & $8(33.3 \%)$ \\
\hline & $P h D$ & $2(33.3 \%)$ & $2(33.3 \%)$ & $3(50.0 \%)$ & $0(0 \%)$ & $7(29.2 \%)$ \\
\hline \multicolumn{7}{|c|}{ Performance time n (\%) } \\
\hline & 1 to 5 years & $0(0 \%)$ & $0(0 \%)$ & $0(0 \%)$ & $1(16.7 \%)$ & $1(4.2 \%)$ \\
\hline & 6 to 10 years & $2(33.3 \%)$ & $2(33.3 \%)$ & $2(33.3 \%)$ & $1(16.7 \%)$ & $7(29.2 \%)$ \\
\hline & 11 to 20 years & $2(33.3 \%)$ & $2(33.3 \%)$ & $4(66.7 \%)$ & $4(66.7 \%)$ & $12(50 \%)$ \\
\hline & more 20 years & $2(33.3 \%)$ & $2(33.3 \%)$ & $0(0 \%)$ & $0(0 \%)$ & $4(16.7 \%)$ \\
\hline \multicolumn{7}{|c|}{ Experience in the area $n(\%)$} \\
\hline & Practical & $1(16.7 \%)$ & $0(0 \%)$ & $0(0 \%)$ & $2(33.3 \%)$ & $3(12.5 \%)$ \\
\hline Practica & 1 and academic & $5(83.3 \%)$ & $6(100 \%)$ & $6(100 \%)$ & $4(66.7 \%)$ & $21(87.5 \%)$ \\
\hline
\end{tabular}

Legend: n: number of judges; \% percentage. Source: Authors (2022).

\section{Concordance analysis}

For the analysis of concordance between the judges, CVI-I was used for each item of the instrument (Calculation 1). 


\section{$C V I-I=\frac{\text { number concordant responses }}{\text { total number of responses }}$}

where,

CVI-I, the Content Validity Index for each item;

number concordant responses, the number of judges who responded to the item as "totally adequate" or "adequate";

total number of responses, the total number of replies reported by the judges. CVI-I values over 0.78 are considered the safest generalization expressing an excellent degree of agreement (Polit \& Beck, 2006).

The seven multiprofessional domain items were questioned to all judges as to their agreement. The other two items depended exclusively on the agreement of the physiotherapist and speech therapist judges, "muscle performance" and "speech and swallowing", respectively. These two items needed a new judgment after the analysis. Thus, were adequate as suggested by the judges.

The second version was sent in its total structure contemplating the nine items, but the evaluation was restricted to the items of physiotherapy and speech therapy domain, which were not validated in the first phase. In the process of judging the speech therapist domain item, one of the judges did not respond to the second validity phase, so this phase was composed of five judges. Post concordance analysis of each item, the CVI-T of the instrument was calculated. This calculation was performed based on the sum of all the CVI-I, divided by the total number of items presented in the instrument.

Post phases of the judges' evaluation, the data was extracted and exported to a spreadsheet in the Microsoft Excel® program, where the statistical analysis was performed.

\section{Results}

The CVI-I and CVI-T values separated by item, in the first phase of validation are shown in Table 2.

Table 2 - content Validity Index of the instrument - analyses of the judges - 1st phase of validation.

\begin{tabular}{|c|c|c|}
\hline \multirow{2}{*}{ Item } & \multicolumn{2}{|l|}{ 1st phase of validation } \\
\hline & Number of judges who considered the item "adequate" or "totally adequate" & CVI-I \\
\hline Identification & 23 & 0.96 \\
\hline Ventilatory History & 20 & $\mathbf{0 . 8 3}$ \\
\hline Vital Signs & 22 & 0.92 \\
\hline Consciousness/Collaboration & 22 & 0.92 \\
\hline Ventilatory Data & 20 & $\mathbf{0 . 8 3}$ \\
\hline Opinion & 20 & $\mathbf{0 . 8 3}$ \\
\hline Legend & 23 & 0.96 \\
\hline Muscular Performance ${ }^{a}$ & 4 & $0.67 *$ \\
\hline \multirow[t]{2}{*}{ Speech and Swallowing ${ }^{\mathrm{b}}$} & 1 & $0.17 *$ \\
\hline & CVI-T & 0.79 \\
\hline
\end{tabular}

a Muscle performance: item questioned only to physiotherapists (6 judges); ${ }^{\text {b }}$ Speech and swallowing: item questioned only to speech therapists (6 judges); * Items with CVI-I less than 0.78. Source: Authors (2022).

Based on Table 2, it can be seen that two items did not reach the minimum value for validation: "muscle performance" and "speech and swallowing". After this analysis, the items were reconsidered as suggested by the judges and sent back to them for second analysis. Chart 1 presents the suggestions proposed by the judges. 
Chart 1 - Suggestions proposed by the judges: physiotherapists and speech therapists.

\begin{tabular}{|c|c|c|}
\hline \multirow{7}{*}{ 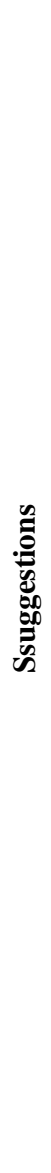 } & Physiotherapists & Speech therapists \\
\hline & $\begin{array}{l}\text { "Add maximum expiratory pressure } \\
(M E P) "\end{array}$ & $\begin{array}{l}\text { "I suggest removing the word vocal quality, as it is not evaluating the type. You } \\
\text { already have the option of being wet. Start straight in Presence of wet voice ... "; } \\
\text { "I suggest going up box the Feeding route before the aspiration signal"; } \\
\text { "Change the acronym for gastrostomy to GTT, as it is GGT (change caption)"; } \\
\text { "I suggest inserting a reference or the name of the scale used in the clinical } \\
\text { evaluation of swallowing" }\end{array}$ \\
\hline & $\begin{array}{c}\text { "The description of manovacuometry on } \\
\text { the methodology, PICO or with } 40 \\
\text { seconds support". }\end{array}$ & $\begin{array}{l}\text { "I would have to ask a question to mark the maximum vocal speech time /a/, /i/ e } \\
\qquad / \mathrm{l} / \text { and the relation } s / z " .\end{array}$ \\
\hline & "Tip: evaluate MIF functionality" & $\begin{array}{l}\text { "In clinical signs of aspiration, place options for these signs; } \\
\text { Cough at what time it occurred; } \\
\text { Leaving colored content after testing would be a classic (saliva) or adapted (food) } \\
\text { test; } \\
\text { Mixed feeding path would be which; } \\
\quad \text { Swallowing assessment what consistencies". }\end{array}$ \\
\hline & - & "TMF /E/, swallowing assessment - reference?" \\
\hline & - & $\begin{array}{l}\text { "Was the Blue Dye Test performed?"Blue Dye Test" What is the observation } \\
\text { period? What is the proposal for the blue dye evaluation protocol? } \\
\text { Aspiration must be broken down: aspiration of food, aspiration of saliva must be } \\
\text { an important aspect to be highlighted. } \\
\text { Test of protective mechanisms..." }\end{array}$ \\
\hline & - & $\begin{array}{l}\text { "I didn't understand if to suggest decannulation, the patient will have the oral } \\
\text { route released? Would the person evaluate the saliva swallowing with dye and the } \\
\text { food at the same time? In the literature this is not a consensus, but in the } \\
\text { flowcharts the published studies suggest that one waits } 24 \text { hours to observe a later } \\
\text { dye output, I believe that this should be clearer, maybe an option would be in the } \\
\text { protocol itself to write that the Blue Dye Test will be performed?" }\end{array}$ \\
\hline
\end{tabular}

Source: Authors (2020).

In the item "speech and swallowing" one of the judges did not participate in the second phase of evaluation and was considered a sample loss, however even if this judge participated in the evaluation and considered the item as not appropriate, even so, the IVC-I value has a higher value than expected for validation. Based on the results presented in Table 2 and 3, the value of CVI-T was 0.90 .

Table 3 - Instrument Content Validity Indexes: muscle performance and speech and swallowing - analysis by the judges - 2nd phase of validation.

\begin{tabular}{cccc}
\hline \multirow{2}{*}{ Item } & \multicolumn{2}{c}{ 2nd phase of validation } \\
\cline { 2 - 4 } & $\begin{array}{l}\text { Number of judges who considered the item "adequate" or "totally } \\
\text { adequate" }\end{array}$ & 5 & $\mathbf{C V I - I}$ \\
\hline Muscle performance & $5^{*}$ & $\mathbf{0 . 8 3}$ \\
Speech and swallowing & & $\mathbf{1}$ & \\
\hline
\end{tabular}

* A speech therapist did not return to the 2 nd phase of validation, therefore, only 5 judges were considered in this analysis. Source: Authors (2020).

\section{Discussion}

The proposal of creation and validity of an instrument has the potential to guide the team in the safe performance of the procedure, because it uses clinical criteria commonly cited as predictors of success. The search for validation evidence makes the instrument safer since it has passed through the analysis of a group of judges with notorious knowledge in the area (Oliveira et al., 2017; Santus et al., 2014). During the construction of the instrument, it was found in the literature that authors 
sought criteria adequate of assisting in the decision making process for tracheal decannulation. Although there is similarity of these criteria among authors, no studies using statistical measures capable of demonstrating evidence of validity were found (Medeiros et al., 2019; Kutsukutsa et al., 2019; Singh et al., 2017).

In this study the criteria listed were organized into nine items of which seven were of multiprofessional domain and two were aimed at specific areas. The proposal of this instrument was to work with multidimensional data, that is, to list items with singularities, but that seek the evaluation of a single final outcome.

By presenting this instrument to the judges in the first phase of evaluation, it was possible to verify the degree of agreement between them, in addition to allowing them to present their suggestions in a qualitative manner, contributing to changes in items and sub-items, suggestions for insertions or exclusions and also the evaluation of appearance (Medeiros et al., 2015; Pernambuco et al., 2017).

As noted in Table 2, the items "identification", "ventilatory history", "vital signs", "awareness/collaboration", "ventilatory data", "opinion" and "caption" obtained values of IVC-I sufficient to be validated, has not undergone any change. The validation of these items in the first phase is probably related to the fact that they have already been described by consensus in the literature (Kutsukutsa et al., 2019). But considering its relevance and the opinion of the judges, the suggestions were accepted (Chart 1).

The "opinion" expresses the result of the analysis of all other items evaluated. The contained items direct to the final decision making whether or not to perform tracheal decannulation. Also in this item, it is possible to suggest referral of the patient for an instrumental assessment of the airways in case it seems unfavorable. Because patients who remain for long periods of tracheostomy or have not had strict control of cuff pressures show a high risk of complications such as malacias or granulomas. These conditions affect the tracheal lumen and can be present in up to $65 \%$ of cases of tracheostomized patients. Changes that compromise 50\% of the tracheal lumen already contraindicate the removal of the cannula (Côrte et al., 2019; Kutsukutsa et al., 2019; Rodrigues \& Nunes, 2015).

The instrument, already in its first phase, reached enough CVI-T to be validated, however considering the importance of the two items that did not reach CVI-I, it was decided to carry out a new phase of evaluation of these items so that it was possible to make the instrument even more qualified. At the end of this last phase, all items reached enough CVI-I for validation, with a new CVI-T $=0.90$ being calculated, so the instrument was fully validated.

The current instrument is a structured model that serves as a guide for professionals making the data measurable and relevant to clinical practice. It is worth emphasizing the importance of having defined and outlined criteria, as this represents an instrument with greater assertiveness.

\section{Conclusion}

Based on the literature, an instrument was developed and which can assist in the process of tracheal decannulation of adults and which was validated in content after two phases of evaluation by a group of experts in the field.

It is recommended to continue the validation process in order to test the reliability and reproducibility of the instrument, through the application of this instrument by professionals in the field.

\section{References}

Avelino, M. A. G., Maunsell, R., Valera, F. C. P., Neto, J. F. L., Schweiger, C., Miura, C. S., Chen, V. G., Manrique, D., Oliveira, R., Gavazzoni, F., Picinin, I. F. de M., Bittencourt, P., Camargos, P., Peixoto, F., Brandão, M. B., Sih, T. M., \& Anselmo-Lima, W. T. (2017). Primeiro Consenso Clínico e Recomendações Nacionais em Crianças Traqueostomizadas da Academia Brasileira de Otorrinolaringologia Pediátrica (ABOPe) e Sociedade Brasileira de Pediatria (SBP). Brazilian Journal of Otorhinolaryngology, 83(5), 498-506. https://doi.org/10.1016/j.bjorl.2017.06.002

Bernardi, S. A. (2016). Artigo de Revisão Cânulas traqueais e disfagia orofaríngea : uma revisão integrativa da literatura. Revistra Brasileira de Cirurgia de 
Cabeça e Pescoço, 44, 187-193.

Côrte, M. M. D. da, Vicente, L. C. C., \& Friche, A. A. de L. (2019). Decanulação: indicadores sociodemográficos, clínicos e fonoaudiológicos preditivos de sucesso TT - Decannulation: sociodemographic, clinical and speech-language indicators predictive of success. Audiol., Commun. Res, 24, e2103-e2103.

de Medeiros, G. C., Sassi, F. C., Lirani-Silva, C., \& de Andrade, C. R. F. (2019). Criteria for tracheostomy decannulation: Literature review. Codas, 31(6), 19. https://doi.org/10.1590/2317-1782/20192018228

Hausberger, S. C., Gomes, H. R., Leonor, V. D., Gaspar, M. do R. de F., \& Santos, R. S. (2016). Proposta de protocolo para decanulação realizada por equipe multidisciplinar. Tuiuti Ciência e Cultura, 52, 11-18.

Hess, D. R., \& Altobelli, N. P. (2014). Tracheostomy tubes. Respiratory Care, 59(6), 956-973. https://doi.org/10.4187/respcare.02920

Hess, D. R., \& Faarc, R. (2005). Facilitating Speech in the Patient With a Tracheostomy. Respiratory Care, 50(4), 519-525. http://rc.rcjournal.com/content/respcare/50/4/519.full.pdf

Hosokawa, K., Nishimura, M., Egi, M., \& Vincent, J. L. (2015). Timing of tracheotomy in ICU patients: A systematic review of randomized controlled trials. Critical Care, 19(1). https://doi.org/10.1186/s13054-015-1138-8

Kutsukutsa, J., Kuupiel, D., Monori-Kiss, A., Del Rey-Puech, P., \& Mashamba-Thompson, T. P. (2019). Tracheostomy decannulation methods and procedures for assessing readiness for decannulation in adults: A systematic scoping review. International Journal of Evidence-Based Healthcare, 17(2), 74-91. https://doi.org/10.1097/XEB.0000000000000166

Medeiros, R. K. da S., Júnior, M. A. F., Pinto, D. P. de S. R., Vitor, A. F., Santos, V. E. P., \& Barichello, E. (2015). Modelo de validação de conteúdo de Pasquali nas pesquisas em Enfermagem. Revista de Enfermagem Referência, 4(IV), 127-135.

Mendes, F., Ranea, P., \& Oliveira, A. C. T. de. (2013). Protocolo de desmame e decanulação de traqueostomia. Revista UNILUS Ensino e Pesquisa, 10(20), 01-12. http://revista.lusiada.br/index.php/ruep/article/viewFile/100/u2013v10n20e69

Mendes, T. de A. B., Cavalheiro, L. V., Arevalo, R. T., \& Soneght, R. (2008). Estudo preliminar sobre a proposta de um fluxograma de decanulação em traqueostomia com atuação interdisciplinar. Einstein (São Paulo), 6(1), 1-6.

O’Connor, H. H., \& White, A. C. (2010). Tracheostomy decannulation. Respiratory Care, 55(8), 1076-1081.

Oliveira, E. L. De, Rocha, C. R., \& Vanvos-sen, M. R. (2017). Critérios Para Decanulação Eficaz: Uma Revisão De Literatura. Movimento e Saúde, 14(47). Pereira, A.S., Shitsuka D.M., Parreira, F.J., Shitsuka, R. Metodologia da pesquisa cietífica. 1ªed. (2018). Santa Maria/RS.

Pernambuco, L., Espelt, A., Magalhães, H. V., \& Lima, K. C. de. (2017). Recommendations for elaboration, transcultural adaptation and validation process of tests in Speech, Hearing and Language Pathology. CoDAS, 29(3), e20160217. https://doi.org/10.1590/2317-1782/20172016217

Polit, D. F., \& Beck, C. T. (2006). The Content Validity Index: Are You Sure You Know What's Being Reported? Critique and Recommendations. ResearchinNursing\&Health, 29, 489-497. https://doi.org/10.1002/nur

Rodrigues, L. B., \& Nunes, T. A. (2015). Importância da broncoscopia flexível na decanulação dos pacientes traqueostomizados. Revista Do Colegio Brasileiro de Cirurgioes, 42(2), 75-80. https://doi.org/10.1590/0100-69912015002003

Santus, P., Gramegna, A., Radovanovic, D., Raccanelli, R., Valenti, V., Rabbiosi, D., Vitacca, M., \& Nava, S. (2014). A systematic review on tracheostomy decannulation: A proposal of a quantitative semiquantitative clinical score. BMC Pulmonary Medicine, 14(1), 1-8. https://doi.org/10.1186/1471-2466-14-201

Singh, R. K., Saran, S., \& Baronia, A. K. (2017). The practice of tracheostomy decannulation-A systematic review. Journal of Intensive Care, 5(1). https://doi.org/10.1186/s40560-017-0234-Z

Souza, A. C. de, Alexandre, N. M. C., \& Guirardello, E. de B. (2017). Propriedades psicométricas na avaliação de instrumentos: avaliação da confiabilidade e da validade. Epidemiologia e Servicos de Saude: Revista Do Sistema Unico de Saude Do Brasil, 26(3), 649-659. https://doi.org/10.5123/S167949742017000300022 